\title{
Evolution of institutions for new industrial policy implementation
}

\author{
Olga A. Romanova
}

\begin{abstract}
A radical restructuring of the global industrial landscape, which involves industrial policy as its main implementation tool, is the crucial peculiarity of economic development today. However, there are still no generally accepted notion of industrial policy, objects of regulation, agreed goals and mechanisms for its implementation. The paper delves into the problems of evolutionary changes in priorities, the central institutions of industrial policy and the development of the conceptual apparatus in this field. Methodologically, the study relies on the synthesis of the provisions of classical institutional theory, the theory of long-term technical and economic development and new structural economics. Comparative research methods and a structural-logical analysis allow the author to scrutinize the changing priorities of industrial policy in Russia, identify the trends in the global technological development that underlie the conceptual principles behind industrial policy implementation in developed countries and establish the most important of them at different stages of the Russian economic development. The author examines tools and forms of industrial policy accelerating the structural transformation of Russia's economy; justifies the need to modify mechanisms and tools of industrial policy implementation; grounds new tasks aimed at identifying the major trends in the formation of network industrial policy.
\end{abstract}

Keywords: evolution; modern industrial policy; tools for industrial policy implementation; forms of industrial policy implementation; business model; digital state; platform company; network industrial policy.

JEL Classification: 014, 025, 032

Funding: the study is prepared in accordance with the research plan of the Institute of Economics of the Ural Branch of the Russian Academy of Sciences for 2019.

Paper submitted: February 26, 2019.

For citation: Romanova O.A. (2019). Evolution of institutions for new industrial policy implementation. Upravlenets - The Manager, vol. 10, no. 3, pp. 14-24. DOI: 10.29141/2218-5003-2019-10-3-2.

\section{INTRODUCTION}

A radical restructuring of the global industrial landscape is the central distinctive feature of today's world largely predetermined by the spreading Fourth Industrial Revolution and the obvious exhaustion of the globalization paradigm of interaction between national economies. Russia's successful participation in the new unfolding revolution and executing the necessary structural maneuver in economy and the social system of the country is one of the central objectives at the present stage of its development. According to the recent calculations, new breakthrough technologies and radical innovations create conditions for a fundamentally different quality of development. By 2030, they are expected to generate from 60 to $80 \%$ of the projected economic growth. The explosive development of breakthrough technologies and a change in the architecture of the markets are forecasted to occur in the period 2020-2030, which will lead to a sweeping change in the structure of the world economy [Dezhina et al., 2015].

Industrial policy as a fast-paced institution of economic activity regulation plays a significant part in this process. Despite the fact that it has been implemented in different countries for more than two centuries, there is still a lack of a unified and clear approach to the very concept of industrial policy, to assessing the role of the state as one of the defining actors of its formation and implementation and to choosing effective mechanisms for implementing managerial decisions. This predetermines the goal of the research which is to identify evolutionary changes in the main components of the Russian industrial policy. To achieve the stated goal, the following tasks should be carried out: to analyse the concept and the objectives of industrial policy; to identify changes in its implementation priorities; to systematize the tools and forms of industrial policy; to develop the necessary modification of its tools; to conceptualize the terms "a digital state" and "platform companies" as new actors of industrial policy.

\section{THE CONCEPT AND OBJECTIVES OF INDUSTRIAL POLICY}

The traditional perception of industrial policy is associated with its role in compensating for market failures, with establishing the government priorities of the national economy development, implementing measures to directly support individual sectors, regulating tariffs, allocating subsidies, giving special preferences and explicit protectionism, etc. With the aggravating instability of economic development, modern industrial policy is characterized by new features related to the support of business and technology initiatives focused on the gain in dynamics. The importance of the support for continuous innovation is growing; the development of human capital is yet the topic of increasing relevance; the development of relations between agents of the innovation process, including business, science (universities), and government authorities, is being stimulated while strengthening the influence of civil society institutions. The spread of the system of horizontal links is becoming increasingly important. The aforementioned new characteristics are fairly significant during the formation of modern industrial policy.

Fig. 1 systematizes the most frequently used and new semantic approaches to the mission of industrial policy. It is worth mentioning that, to date, the most widespread slant observed in monographs and periodicals is dealing with industrial policy as a tool for a purposeful change in the 


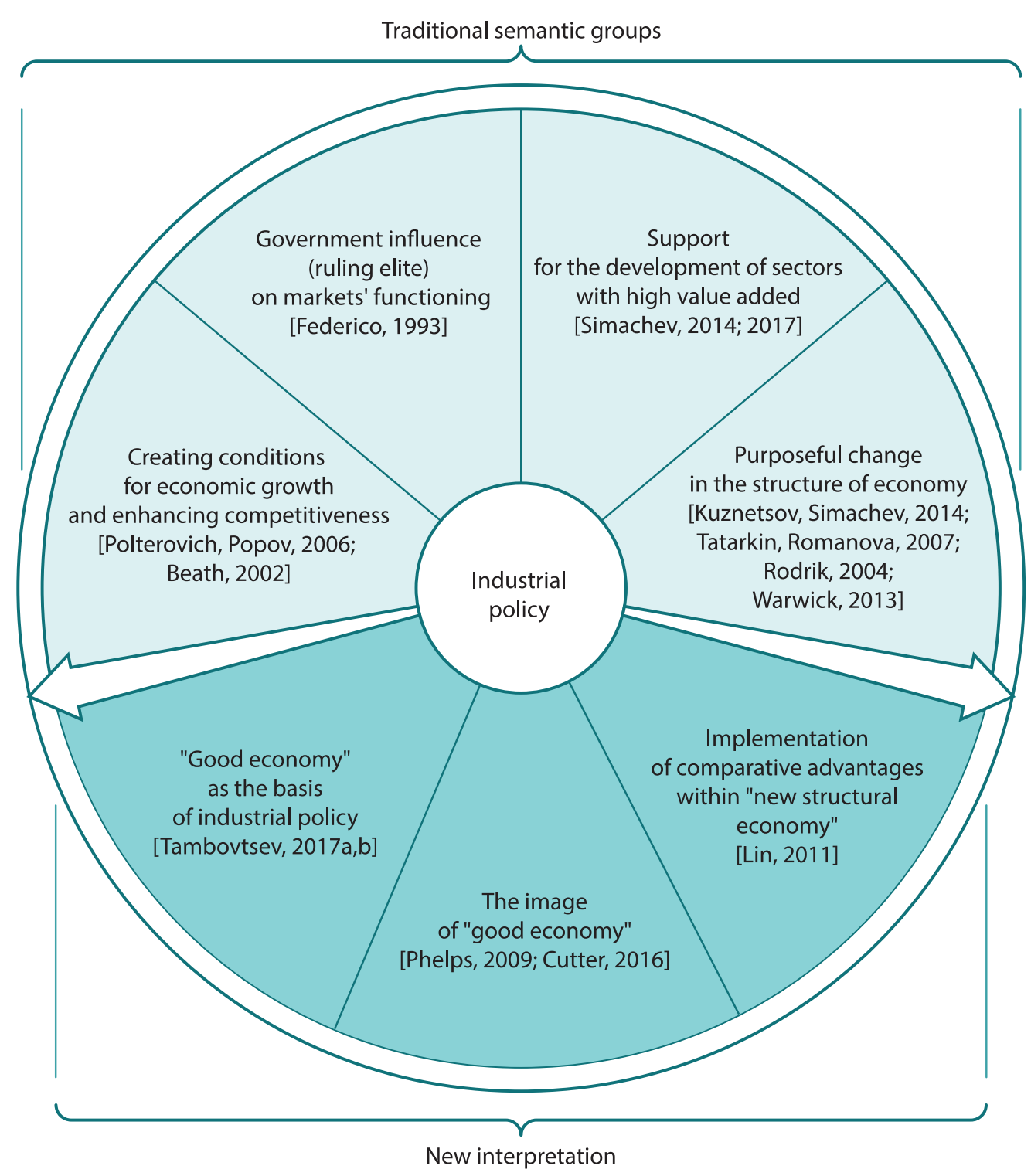

Fig. 1. Traditional and new interpretations of industrial policy objectives ${ }^{1}$

Рис. 1. Традиционный и новый подходы к пониманию целей промышленной политики

structure of economy. The institution of industrial policy is undergoing permanent changes; not only the mechanism for achieving the stated goals but also the goals themselves evolved significantly during the period from the 19th century to the first decades of the 21 st century.

The determining factor of such changes was the evolution of the state as the main subject of industrial policy implementation. By the early 20th century, it became obvious that the notions of progress are predetermined by three interdependent development factors: the improvement of production technologies, the development of institutions and the level of culture. At that time, the development of the mechanisms for supporting technological revolution accompanied by the evolution of laissez faire institutions commenced playing a pivotal role in shaping the public policy in the West.

\footnotetext{
${ }^{1}$ Note. Based on: [Rodrik, 2004; Kuznetsov, Simachev, 2014; Tatarkin, Romanova, 2007; Polterovich, Popov, 2006; Beath, 2002; Federico, Foreman-Peck, 1999; Dementyev, 2013; Warwick, 2013; Lin, 2011; Cutter, Litan, Stangler, 2016; Phelps, 2007; Phelps, 2009; Tambovtsev, 2017a,b].
}

The consequences of the Crisis of the 1930s and the Second World War resulted in the consolidation of society in the countries opposing fascism, determined the need for to use centralized mechanisms for the distribution of scarce goods, which led to a change in the balance of power in the confrontation between the market-related and dirigisme ideologies. In that period, due to the growth in welfare and mass culture in the Western world, society's attitude to problematic aspects of competitive mechanisms, which aggravated the problem of inequality, unemployment, etc., became more negative. This resulted in the emergence of the mainstream concept of the welfare state. This radically changed the perception of the role of power [Polterovich, 2018, p. 89]. The prevailing idea is that it is necessary to look at society as a unified whole that makes it possible for power to provide everyone with not minimal but acceptable levels of social standards. The evolution of the state caused serious changes in the objectives of the state industrial policy spreading them from exclusively the technological sphere to the field of the socio-economic development. 
The analysis of the world practice of shifts in industrial policy priorities over the past two centuries demonstrates this trend clearly and distinctly. There are three most characteristic stages of such changes:

1) from the late 19th century to the first decades of the 20th century. The primary objective of industrial policy was to establish a strong industry, and the social aspect was taken into account only from the standpoint of preventing serious social cataclysms;

2) from the first decades to the 60s-70s of the 20th century. During this stage it was obligatory to support such a level of industrial development which provided the most important social guarantees;

3) the present time. The modern stage of industrial policy development is characterized by the fact that in developed countries it is possible to implement only that industrial policy which respects the prevailing social interests.

In Russia, unfortunately, the concept of industrial policy evolved in the opposite direction. One of the first concepts proposed by the Chamber of Commerce and Industry of the Russian Federation in 1998 (a turning point both in the trends of Russia's economic development and political ideology) defined industrial policy as a system of measures aimed at developing the national economy, state-of-the-art technologies, modern information-related and other services for human development. Within the framework of this definition, the whole national economy was assumed as an object of industrial policy and the importance of human development was emphasized.

However, in 2014 the law "On industrial policy in the Russian Federation" was approved at the federal level that stipulated the so-called narrow concept of industrial policy, the object of which was solely Russia's industrial potential excluding any objectives implying the achievement of certain social standards.

The abovementioned systematization of the current concepts of industrial policy and the analysis of similar definitions proposed in the Russian economic sphere allow concluding that the most appropriate interpretation is given by UNIDO and OECD. These organizations regard industrial policy as any type of intervention or government policy that attempts to improve the business environment or to alter the structure of economic activity toward sectors, technologies or tasks that are expected to offer better prospects for economic growth or societal welfare than would occur in the absence of such intervention [Warwick, 2013; Pack, Saggi, 2006]. Improving the structure of economic activity and the importance of social welfare's growth are the most significant accents when providing further clarification of the concept of industrial policy.

\section{A SHIFT IN INDUSTRIAL POLICY PRIORITIES}

Industrial policy is a flexible tool to implement the priorities of technological and socio-economic development that were subjected to multiple changes in Russia. The financial crisis of 2008 had a debilitating effect on the Russian economy which demonstrated the most drastic decrease in the key indicators of economic development. Under these conditions, there was a gain in the number of research studies on the identification of such priorities of industrial policy, the implementation of which could, on the one hand, reduce the impact of crisis factors, and on the other hand, create the basis for future sustainable development. Having systematized these studies, we identified the following top priorities:

- preserving the industrial and technological potential of future growth (rejection to keep inefficient production);

- maintaining the domestic demand from the state (government investment and government procurement);

- supporting long-term priorities of the country's modernization; the shift in the model of economic growth (the transition from "oil" growth to innovation);

- lifting administrative barriers for business; implementing a new set of measures that allows small business to develop successfully amid crisis.

Among the highlighted priorities, the special attention was given to anti-crisis modernization of the Russian economy, which could result in its structural renewal and reduce the dependence on the export of fuel and raw materials. During this period, as a respond to the crisis, the state increased its share in the ownership of economic entities while commenting on its reduction as the situation stabilized. The major priorities embraced the mitigation of regional polarization by accelerating the evolution of depressed and poor-developed regions, as well as the development of the strategic management system at regional level. The special focus was placed on designing regional industrial policy because since 1998-1999, in the absence of the federal law on industrial policy, the RF subjects commenced developing their own regional laws. More than fifty regions of the Russian Federation introduced such laws that demonstrated an extremely heterogeneous understanding of industrial policy, the contradictory formulation of its objectives, tasks and implementation mechanisms. This required bringing them into a form acceptable for comparing.

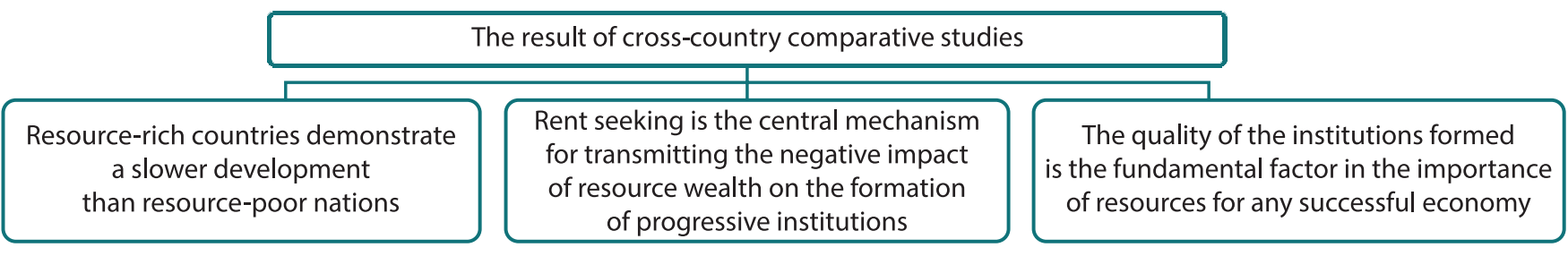

Fig. 2. Industrial policy in a resource dependent economy

Рис. 2. Промышленная политика в ресурсозависимой экономике 
After the crisis of 2008, the problem of resource dependence of the Russian economy received meticulous attention. The Institute of Economics of the Ural Branch of the RAS has conducted a number of studies on comparative analysis of industrial policy models in different economies characterized by the so-called "resource wealth". The main findings of the research are presented in Fig. 2. They prove that the development of the global economy has passed the stage when being rich in natural resources and cheap labour was the main growth factor.

As shown in Fig. 2, the quality of the institutions formed plays the instrumental role in the successful development of the country's economy which possesses abundant and diverse resources. In the context of the post-crisis development of the Russian Federation, the improvement of the industrial policy institution was aimed at not only technological modernization, diversification of the economic structure, innovation in the field of advanced technologies and new markets, but also the redistribution of the resource rent. During this period, the strategy for implementing Russia's industrial policy took into account the importance of investing in prioritized non-primary sectors, infrastructure and education for the benefit of all non-primary sectors.

In May 2012, the RF President Vladimir Putin issued the so-called "May Decrees" which proclaimed new industrialization as the central trend in Russia's economic development at the present stage. New industrialization became the mainstream of the country's industrial policy. In Russia, new industrialization is viewed as a process of spreading breakthrough technologies that cover both the formation of new industries (industrial sectors) and their advancement in traditional industries [Lenchuk, 2016].

Due to the adoption of the new industrialization concept, the priorities of industrial policy were changed once again. The most significant of them are:
- digitalization of production, microprocessor revolution, robotization, labour saving, green economy, the Internet of Things;

- reorientation of engineering and technological systems towards environmentally friendly ones;

- modernization of the existing production based on "nature-like technologies";

- strengthening the role of not only venture companies, but also industry companies with strong infrastructure, finance and ties with the state.

\section{THE DEVELOPMENT OF THE DIGITAL ECONOMY AS A PRIORITY OF MODERN INDUSTRIAL POLICY}

Today, new global technological trends associated with the development of the Fourth Industrial Revolution and the digital economy are becoming increasingly clear. Among the most important trends exerting a direct influence on the Russian industrial policy under the new conditions are the following: the use of digital and information technologies as the basis for all new technological solutions; non-linear highest rates of development; unprecedented changes in the paradigms of economy, business, society; the increasing role of companies that create platforms and form business ecosystems on this basis. Growing social and ethical responsibility of both the state and business is one of the crucial and most significant trends in the global development that have to be accounted for in modern industrial policy.

Taking into account the above-mentioned general features of the new world trends, we can identify the conceptual specificity of their implementation in the world economy (Table 1).

It is worth emphasizing that the primary tasks of the EU countries' industrial policy are to form a single digital market and to consolidate the strategies for the domestic market development, as well as to create a favourable institutional

Table 1 - Conceptual specificity of implementing the principles of the digital economy in developed countries Таблица 1 - Концептуальные особенности реализации принципов цифровой экономики в развитых странах

\begin{tabular}{|l|l|}
\hline \multicolumn{1}{|c|}{ Country } & \multicolumn{1}{c|}{ Determining conceptual principle } \\
\hline $\begin{array}{l}\text { EU countries, } \\
\text { including: }\end{array}$ & $\begin{array}{l}\text { The strategy of a single European digital market implemented in the three directions: facilitating the access of } \\
\text { customers and business to products and services via the Internet within the European Union; creating a favourable } \\
\text { environment for the development of digital networks and services; boosting the maximum growth of the European } \\
\text { digital economy }\end{array}$ \\
\hline Germany & $\begin{array}{l}\text { Industry 4.0; economic transition to digital production; introduction of digital technologies in the daily life of society } \\
\text { based on the implementation of the program "Digital Strategy - 2025" “DE.DIGITAL") }\end{array}$ \\
\hline France & Factory of the Future (Usine du Futur) \\
\hline Netherlands & Smart Factory \\
\hline United Kingdom & $\begin{array}{l}\text { The country is the world leader in building cyberspace. } \\
\text { Manufacturing products with high value added (High Value Manufacturing Catapult) }\end{array}$ \\
\hline USA & $\begin{array}{l}\text { The country's dominant role in developing standards and "the rules of the game" within multilateral agreements. } \\
\text { The Industrial Internet }\end{array}$ \\
\hline China & $\begin{array}{l}\text { Internet Plus strategy. The purpose is to integrate the Internet, cloud computing, big data and the Internet of Things } \\
\text { with modern production in order to develop industrial networks, electronic commerce and online banking, as well } \\
\text { as to intensify the international presence of Chinese companies online }\end{array}$ \\
\hline Japan & The creation of new society using human-oriented information technology \\
\hline India & The Digital India programme. Its purpose is to turn the country into digital society and knowledge economy \\
\hline
\end{tabular}

Note. Based on: [Revenko, Revenko, 2017; Popov, Semyachkov, 2018; Idrisov et al., 2018; Ipatova, Shitova, 2018]. 
environment for accelerating technological progress. The main priority of industrial policy in these countries is to train a highly skilled workforce focused on the work in the digital economy, as well as on the growth of labor productivity. A successful initiative extending the institutional field of industrial policy in the European Union is to develop a roadmap in the field of digital education. It is aimed at expanding the use of digital technologies, improving the quality and accessibility of educational services; broadening skills and competences in accordance with the technologies of Industry 4.0. The key principle of the EU industrial policy is to provide all the states with open and equal access to diverse markets for technologies, products, services and resources [Ipatova, Shitova, 2018, p. 55].

In Russia, the "digital agenda" is also being actively formed. The Federal Program "The Digital Economy in the Russian Federation" is designed to ensure the development of digital technologies, primarily in the field of public administration, healthcare and the creation of a "smart city" real sector of the economy and the industry, in particular, have not received the necessary development impetus in terms of applying digital technologies in their production activities. As for digitalization of such economic activities as manufacturing, the oil and gas industry and mining, which are of special importance for Russia, the country's economy lags behind the leading nations of the European Union by more than 50\% [Grammatchikov, 2017]. Moreover, the technologies underlying the digital economy are expected to be introduced into the common use, which allows all members of society to use their advantages. One of the factors stimulating this process is the creation of higher education institutions in the Russian Federation, in particular, the creation of five "digital" universities.

The digital transformation of the Russian economy is becoming one of the major priorities of modern industrial policy, which requires its implementation mechanisms to be targeted at radical structural changes. The structure of economy as a socio-economic system is characterized by not only the relations between the system's elements determined in accordance with the analysis conducted, but also the organization of relations, as well as the relations between the subsystems and the system's elements. The conservation of the economic development's structural characteristics that occurred in the period from 2008 to 2016 initiated a transition of economic dynamics into the phase of stagnation, which lured the Russian economy into the trap of a simplified economy with a low level of technological development [Shirov, 2018, p. 29]. An economy, the structure of which does not change under the influence of the challenges and constraints of development, is doomed to stagnation and gradual degradation of economic ties. Ignoring the structural factors when framing industrial policy leads to the unjustified prioritization of certain industries over the others,

\footnotetext{
"The Federal Program "The Digital Economy of the Russian Federation" is approved by the decree of the RF Government of July 28, 2017 no. 1632-r. Available at: http://static.government.ru/media/files/9gFM4FHj4PsB7915v 7yLVuPgu4bvR7M0.pdf (in Russ.).
}

substituting the domestic products with imports, etc. In the absence of a well-thought-out industrial policy, serious complications cause structural imbalances which can be gradually transformed into sustainable limitations of the economic development.

One of the most noticeable disproportions in the Russian economy highlighted by both domestic and foreign economists is the discrepancy between the development level of the military-industrial complex (MIC) and the country's consumer complex. Yaremenko [1997a,b] and Lin [2011] look at this structural disproportion as the most serious threat to the country's development in the long run. In this respect, we question the fairness of Sychev's statement about the military-industrial complex as the primary priority of the Russian economy's development. According to Professor Sychev [2018, p. 39], the complex can serve as a multiplier that involves civilian industries in the use of high technologies. Without a doubt, the prioritized development of the military-industrial complex as a multiplier can produce a significant effect, but, in our opinion, it cannot compensate for the ever-increasing gap between the MIC technological level and civilian industries.

A new structural imbalance that is becoming increasingly important is a scrupulous attention of the state to the functioning and supporting large enterprises, whereas the development potential of medium-sized companies in the context of the formation of new technological trends is gaining in relevance. The urgency of supporting medium-sized businesses increases significantly amid the development of network production, modular organization of enterprises, and the outsourcing of a number of functions, including research studies, which impairs the competitiveness of large industrial complexes. In addition, medium-sized enterprises are not bound by rigid corporate norms and various bureaucratic superstructures; they are more adaptable to ideas dictated by the Fourth Industrial Revolution. It is of great importance that the mass character of medium-sized enterprises allows avoiding or mitigating the risks of erroneous choice of the development priorities.

An in-depth analysis of the growth dynamics and structural shifts in the medium-sized industrial business in the Middle Ural performed by Maltsev and Maltseva [2018, p. 109] demonstrated that in the period from 2008 to 2016 , the region's medium-business showed a fairly steady growth - 83 business entities in 2008 and 99 business entities in 2016. During the same period, the number of the leading large economic entities of the Middle Ural industry decreased from 97 to 92 . In 2008-2016, the medium-sized industrial business in the Middle Ural increased 2.3 times, whereas the total industrial production of large enterprises rose only 1.7 times.

\section{INDUSTRIAL POLICY:TOOLS AND FORMS}

The tools of industrial policy should be more aimed at reducing numerous structural disproportions in the development of the Russian economy. The period of 1994-2019 was characterized by the active formation of the tools and large-scale experiments conducted in this field. Institutional 
forms and methods of industrial policy implementation underwent important changes as well. In the period from 1994 to 2009 , the federal target-oriented programs, which evolved into the state programs in 2010, represented a particularly significant form of industrial policy implementation. It is noteworthy that today the state programs are more of a rigid expenditure management tool rather than an instrument of strategic planning characterized by considerable flexibility in decision-making. The adoption of the Federal Law on Public-Private Partnership (PPP) in 2015 made it possible to deal with it as the new institutional mechanism for enforcing industrial policy ${ }^{1}$. However, public-private partnership as a special form of interaction between economic agents - the state and business - did not produce the desirable effect at that time. The creation of state corporations at the next stage was in fact one of the consequences of the refusal of the state to search for effective PPP methods. Thus, one of its most important and promising mechanisms, namely public-private partnership, was removed from the general institutional field of industrial policy which found itself trapped solely within the public sector of the economy.

The most effective tools of industrial policy in the period of Russia's post-crisis economic development (2009-2011) embraced government guarantees, financial support and demand support for 197 system-forming organizations. During that period, innovation was further stimulated and its primary tools included nationwide innovation projects, innovation venture funds, university innovation support programs, the creation of an innovation infrastructure including the Skolkovo innovation center and the formation of "technological valleys" in the regions, i.e. science and technology centers. The tools designed to raise the level of technological development of the Russian economy were innovation development programs (IDPs) of partially and fully government-owned corporations operating in knowledge-intensive industries. There was a significant rise in costs incurred in technological innovation of industrial organizations owned by state corporations. From 2010 to 2015, this indicator increased 26 times [Idrisov et al., 2018, p. 12].

${ }^{1}$ The Federal Law "On public-private partnership and municipalprivate partnership in the Russian Federation and making amendments to certain statutory laws of the Russian Federation" of July 13, 2015 no. 224-FZ. Available at: http://www.consultant.ru/document/cons_doc_ LAW_182660/ (in Russ.).
Nevertheless, the creation of the Industrial Development Fund (IDF) and the Special Investment Contract (SIC) enshrined in the Federal Law "On Industrial Policy in the Russian Federation" were the principal changes in industrial policy. The IDF has proven itself to be an effective tool to support the changing priorities of industrial policy. One of the new priorities financed by the Fund in 2018 was the program "Digitalization of Industry". To a certain extent, the program compensates the Federal Program "The Digital Economy in the Russian Federation" that lacks the measures related to the digitization of the real economy. It is also of high importance that the Fund supports development projects implemented in the field of import substitution, export and introduction of the best available technologies (BAT). As of March 22,2019 , the Fund financed 383 projects totaling 86.3 billion rubles; $35 \%$ of them ( 135 projects) are those implemented in mechanical engineering; $12.2 \%$ (47 projects) - in chemistry; $11.5 \%$ (44 projects) - in metallurgy (Table 2$)^{2}$.

The subjects of the Russian Federation form their regional IDFs; eighty-two agreements on cooperation with regions were signed. The leading regions in the number of projects implemented are Moscow oblast (34 projects), Sverdlovsk oblast (24 projects) and the Republic of Tatarstan (20 projects). The experience of co-financing priority programs related to development projects and components by federal and regional IDFs has proved to be successful. Financing is carried out in accordance with the agreement between the IDF and the regional IDF in the ratio of $70 \%$ (federal funds) to $30 \%$ (regional funds).

However, it is worth noting that the IDF supports primarily mature industries, start-ups are funded by the Skolkovo Foundation and the projects on the development of hightech industries suffer from a lack of effective support mechanisms. We believe that this situation can be improved though the activation of the Special Investment Contract mechanism that is aimed at supporting decisions on high-tech industries' development. The SIC mechanism has been functioning since 2015. By the first quarter of 2019, 35 investment contracts were signed; their industry distribution is shown in Fig. 3.

${ }^{2}$ The Industrial Development Fund. The opportunities for project financing. Available at: http://frprf.ru/download/prezentatsiya-fonda-narusskom-yazyke.pdf (in Russ.).

Table 2 - New financing priorities of the Industrial Development Fund in 2018 Таблица 2 - Новые приоритеты финансирования Фонда развития промышленности, 2018 г.

\begin{tabular}{|l|c|c|c|}
\hline \multicolumn{1}{|c|}{ Programs financed by the Industrial Development Fund } & Loan size, million rubles & Interest rate, $\%$ & Loan term \\
\hline Digitalization of industry & $20-500$ & $1-5$ & Up to 5 years \\
\hline Development projects (import substitution, BAT, export) & $50-500$ & $3-5$ & Up to 5 years \\
\hline Machine tool industry & $50-500$ & $1-5$ & Up to 7 years \\
\hline Conversion & $80-750$ & $1-5$ & Up to 5 years \\
\hline Components & $50-500$ & $1-5$ & Up to 5 years \\
\hline Increase in labour productivity & $50-300$ & 1 & Up to 5 years \\
\hline Leasing projects & $5-500$ & 1 & Up to 5 years \\
\hline Drug labeling & $5-50$ & 1 & Up to 2 years \\
\hline
\end{tabular}




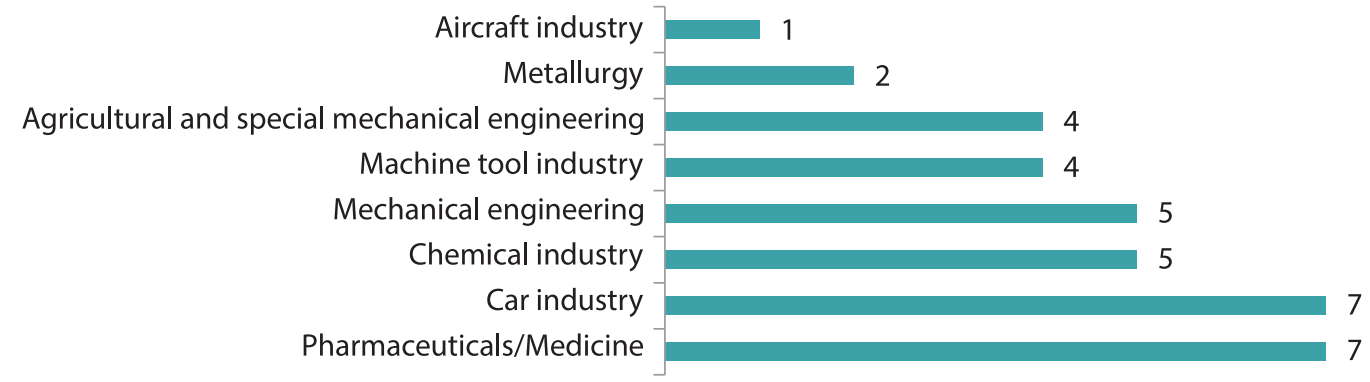

Fig. 3. Distribution of the SIC by industries in $2018^{1}$

Рис. 3. Отраслевое распределение специальных инвестиционных контрактов, 2018 г.

The total sum of investment contracts amounted to 438.3 billion rubles; the number of jobs created was $17,669^{2}$. However, the introduction of the draft Federal Law" On Protection and Encouragement of Capital Investment in the Russian Federation and Amendments to Certain Legislative Acts of the Russian Federation" ${ }^{\prime \prime}$, the purpose of which is to attract investment in the Russian economy, seriously changes some fundamentally important provisions for concluding contracts. The RF government is going to make amendments to the Federal Law "On Industrial Policy in the Russian Federation" with regard to new conditions and regulation of the SIC. Conceptual changes are made in the following spheres: the purpose of concluding a special investment contract; evaluation of applications for entering into a contract; participation of the region and municipality in fulfilling the contract; access to subsidy support. The primary purpose of concluding the SIC-1 was to create, modernize (including the introduction of BAT) or develop production, whereas the purpose of the SIC-2 is to design and/or introduce new technologies. At the same time, modern technologies are interpreted as technologies for producing products that are competitive in the world market or have no analogues manufactured in the Russian Federation. The list of such technologies is approved

\footnotetext{
${ }^{1}$ Note. Complied using the data from the IDF official website. Available at: http://frprf.ru/.

${ }^{2}$ The Industrial development Fund. Opportunities for project financing. Available at: http://frprf.ru/download/prezentatsiya-fonda-narusskom-yazyke.pdf.

${ }^{3}$ The draft Federal Law "On Protection and Encouragement of Capital Investment in the Russian Federation and Amendments to Certain Legislative Acts of the Russian Federation". Prepared by the Ministry of Finance of the Russian Federation as of October 26, 2018. Available at: http://www. consultant.ru/cons/cgi/online.cgi?base $=P R J \& d s t=\& n=177555 \&$ req $=d$ oc\#06504714466027548.
}

by the Government of the Russian Federation. Another novel aspect is the evaluation of applications for entering into a contract within the competitive admissions framework, but not on a rolling basis. Competitive selection can be of two types, i.e. open and closed. The latter is held in response to the development of military, special-purpose and dual-use technologies to ensure the national defense and the security of the state. There also exist the grounds for rejecting competitive selection, such as concluding a SIC as decreed by the RF President, if there is only one investor partaken in the bidding, etc. There was a fundamental change in the opportunities for the region and municipality to take part in making a special investment contract. In the SIC-1, their participation was dependent on the measures requested by the investor, but according to the SIC-2, the participation of the region and municipality is obligatory. The access to subsidy support, which was previously lent within the budget allocations for the fiscal year, was also expanded; as stipulated by the SIC-2, the support is provided for the entire period of the SIC implementation.

The conditions for concluding the SIC-2 were also subject to significant changes (Table 3).

The SIC-related amendments are introduced in the Federal Law "On Industrial Policy in the Russian Federation" and the country's Tax Code. In our view, the repeal of the provision of the Federal Law "On Industrial Policy in the Russian Federation" on the non-deterioration of tax conditions is the most controversial of them. The provision is non-applicable to VAT when concluding the SIC-2. With all the possible benefits of the draft Federal Law "On Protection and Encouragement of Capital Investment in the Russian Federation and Amendments to Certain Legislative Acts of the Russian Federation",

Table 3 - Shifts in the conditions for concluding a special investment contract in 2019 Таблица 3 - Изменение условий заключения специального инвестиционного контракта, 2019 г.

\begin{tabular}{|l|l|l|}
\hline \multicolumn{1}{|c|}{ Indicator } & \multicolumn{1}{c|}{ SIC-1 } & \multicolumn{1}{c|}{ SIC-2 } \\
\hline Contract term & Up to 10 years & $\begin{array}{l}\text { Up to } 15 \text { years, if total investment is } \leq 50 \text { billion rubles } \\
\text { Up to } 20 \text { years, if total investment is }>50 \text { billion rubles }\end{array}$ \\
\hline Total investment & Starting from 750 million rubles (ex VAT) & Starting from 1 billion rubles (ex VAT) \\
\hline Number of investors & One investor & Several investors possible \\
\hline Corporate tax & $\begin{array}{l}\text { Preferential rate applied when forming at least 90 \% } \\
\text { of revenues from selling the SIC products }\end{array}$ & $\begin{array}{l}\text { Possibility to apply a preferential rate to the taxable base } \\
\text { of the SIC products }\end{array}$ \\
\hline Government support & Unlimited & $\begin{array}{l}\text { Tax and non-tax budget expenses incurred in the project }- \\
\text { no more than 50\% of capital investment }\end{array}$ \\
\hline
\end{tabular}


the repeal of the provision on the non-deterioration of tax conditions for the SIC participating parties can aggravate the distrust in the government guarantees of stability. The new mechanism of the SIC-2 and first tenders are expected to be triggered in the third quarter of 2019.

It is obvious that the abovementioned tools of industrial policy, their further adjustment in accordance with the requirements of the Fourth Industrial Revolution will be quite effective, mainly from the standpoint of modernization of traditional industries and business operations within traditional industry markets. However, due to the high uncertainty and riskiness of their implementation, the choice of industrial policy's priorities in the field of new industries advanced development requires new approaches to be applied. According to Idrisov [2018, p. 22], a promising model for the implementation of such priorities is experimental, strategic project initiatives, the implementation of which will require special project offices to be created.

It seems expedient to establish project technological consortia that, as the global practice demonstrates, are quite successful and effective. The USA, Japan and the EU countries used consortia to speed up the development of entire technological complexes. It is also promising to create research and production consortia that are supposed to unite enterprises in the real sector of economy, scientific organizations and higher educational institutions. The activity of such consortia should be based on public-private partnership tools. The extensive global experience in the formation of consortia indicates that, as flexible organizational structures of network interaction, these consortia are successfully used to develop certain high-tech areas. Their functioning ensures the production of high-tech goods and services highly competitive in the world market.

One of the main characteristics of modern economy is its gradual transformation into a global network market, the configuration of which is significantly altered by both technological and institutional changes. Evolution of industrial markets and the formation of a brand-new world network market entrust both the state and business with the task to tackle new challenges in the field of industrial policy. The vanishing boundaries within the market and even between the markets for technologically different products and services do not provide the clear picture for choosing the objects of state support through the industrial policy mechanisms. Business is also increasingly uncertain about real competitors in the market and future positions of the leading business structures.

\section{THE DIGITAL STATE AND PLATFORM COMPANIES}

The cardinal changes happening in the modern economy cause new concepts of the state to emerge, in particular, the concept of a digital state (e-state) which exerts a direct effect on the content and tools of industrial policy. The concept is premised on the understanding of the role of a digital state as not just a new player providing services and exercising data-based government management, but as a subject responsible for the creation of new digital public goods that are gaining in popularity among citizens. In a digital state, the problem of finding a new balance between the technological and social aspects of industrial policy is becoming especially acute.

The explosive development and the ever accelerating spread of digital technologies with their penetration into all areas of human activity result in fundamental changes not only in the state, but also in the business models of companies. Business models refer to the ways of business organization that mirror the economic logic of the activities of companies and its partners focused on creating value for consumers. Platform-based business models are becoming more and more widespread. These are the so-called platform companies that turn into new business subjects [Markova, 2018 , p. 127]. They gain in market power, provide a transition from value chains to collaboration (partner networks) and create the environment for the co-evolution of markets and companies. Based on the real parameters and key processes of platform-based business models, there emerges an opportunity to substantiate various priorities of industrial policy. This might be an emphasis on encouraging the development and production of technologically advanced products; facilitating communication between a platform's participants and access to the market, and developing the business ecosystem in concert with the partners.

Amid ultra-fast changes, increased demands are made not only for the core competencies of state authorities at different levels and platform companies' participants, but also for managers, whose skills and expertise are vitally important for a technological breakthrough. Managers who implement the priorities of industrial policy should become highly qualified specialists in the development of particular industries, allow for their dynamic integration into complex intersectoral associations and comprehend the new architecture of the industrial landscape [Gitelman, 2018].

\section{CONCLUSION}

Today, the possibility of integrating into the global technological chains and increasing the number of its links through outsourcing and production specialization are no longer the main factors in scientific and technological progress and do not determine the competitive advantages of a country or individual business entities. In this context, there is an active search for a new paradigm of industrial activity, which inevitably entails a search for new approaches to the understanding of the specificity of modern industrial policy and to the formation of the so-called network industrial policy. Studying its economic content, priorities and implementation mechanisms is the subject of future research. 
Gitelman L.D. (2018). Menedzhery, deystvuyushchie na operezhenie: universitety i novaya industriya [Proactive managers: universities and new industry]. Moscow: Ekonomika.

Grammatchikov A. (2017). Tsifrovaya realnost [The digital reality]. Ekspert - Expert, no. 29(1038), pp. 13-17.

Dezhina I.G., Ponomarev A.K., Frolov A.S. et al. (2015). Novye proizvodstvennye tekhnologii: publichnyy analiticheskiy doklad [New production technologies: public analytical report]. Moscow: Delo.

Dementyev V.E. (2013). Strukturnye faktory tekhnologicheskogo razvitiya [Structural factors of technological development]. Ekonomika i matematicheskie metody - Economics and Mathematical Methods, vol. 49, no. 4, pp. 33-46.

Idrisov G.I., Knyaginin V.N., Kudrin A.L., Rozhkova E.S. (2018). Novaya tekhnologicheskaya revolyutsiya: vyzovy i vozmozhnosti dlya Rossii [New technological revolution: Challenges and opportunities for Russia]. Voprosy ekonomiki - Issues of Economics, no. 4, pp. 5-25.

Ipatova A.V., Shitova A.S. (2018). Institutsionalizatsiya neoindustrial'noy promyshlennoy politiki: mirovoy opyt i vozmozhnosti dlya Rossii [Institutionalization of neo-industrial industrial policy: world experience and opportunities for Russia]. Ekonomika i upravlenie - Economics and Management, no. 10(156), pp. 50-59.

Kuznetsov B.V., Simachev Yu.V. (2014). Evolyutsiya gosudarstvennoy promyshlennoy politiki v Rossii [Evolution of the state industrial policy in Russia]. Zhurnal Novoy ekonomicheskoy assotsiatsii - Journal of the New Economic Association, no. 2(22), pp. 152-179.

Mal'tsev A.A., Mal'tseva V.A. (2018). Sredniy biznes promyshlennosti regiona: dinamika rosta i strukturnye sdvigi [Medium-sized industrial enterprises in a region: An overview of the development]. Izvestiya Uralskogo gosudarstvennogo ekonomicheskogo universiteta - Journal of the Ural State University of Economics, vol. 19, no. 6, pp. 101-113.

Markova V.D. (2018). Biznes-modeli kompaniy na baze platform [Platform-based business models of companies]. Voprosy ekonomiki - Issues of Economics, no. 10, pp. 127-135.

Lenchuk E.B. (ed.). (2016). Novaya promyshlennaya politika Rossii v kontekste obespecheniya tekhnologicheskoy nezavisimosti [New industrial policy of Russia in the context of ensuring technological independence]. St. Petersburg: Aletiya.

Polterovich V.M. (2018). K obshchey teorii sotsial'no-ekonomicheskogo razvitiya. Chast' 2. Evolyutsiya mekhanizmov koordinatsii [Towards a general theory of socio-economic development. Part 2. Evolution of coordination mechanisms]. Voprosy ekonomiki - Issues of Economics, no. 12, pp. 77-102.

Polterovich V.M., Popov V.V. (2006). Evolyutsionnaya teoriya ekonomicheskoy politiki [An Evolutionary Theory of Economic Policy]. Voprosy ekonomiki - Issues of Economics, no. 7, pp. 4-23.

Popov E.V., Semyachkov K.A. (2018). Komparativnyy analiz strategicheskikh aspektov razvitiya tsifrovoy ekonomiki [Comparative analysis of strategic aspects of development of digital economy]. Vestnik Permskogo universiteta. Seriya: Ekonomika Perm University Herald. Economy, vol. 13, no. 1, pp. 19-36.

Revenko L., Revenko N. (2017). Mezhdunarodnaya praktika realizatsii programm razvitiya tsifrovoy ekonomiki [International practice of implementing digital economy development programs]. Mezhdunarodnye protsessy - International Processes, no. 4, pp. 20-39.

Sychev N.V. (2018). Novaya strategiya promyshlennoy politiki i ee rol'v modernizatsii rossiyskoy ekonomiki [New strategy of industrial policy and its role in the modernization of the Russian economy]. Ekonomicheskie strategii - Economic Strategies, no. 7, pp. 32-39.

Tambovtsev V.L. (2017a). Nuzhdaetsya li promyshlennaya politika v teoreticheskikh opravdaniyakh? [Does industrial policy need theoretical justifications?]. Voprosy ekonomiki - Issues of Economics, no. 5, pp. 29-45.

Tambovtsev V.L. (2017b). Promyshlennaya politika: k novomu ponimaniyu [Industrial policy: towards new interpretation]. Izvestiya Uralskogo gosudarstvennogo ekonomicheskogo universiteta - Journal of the Ural State University of Economics, no. 5(73), pp. 54-67.

Tatarkin A.I., Romanova O.A. (2007). Promyshlennaya politika i mekhanizm ee realizatsii: sistemnyy podkhod [Industrial policy and the mechanism of its implementation: a systematic approach]. Ekonomika regiona -Economy of Region, no. 3, pp. 19-31.

Shirov A.A. (ed.). (2018). Transformatsiya struktury ekonomiki: mekhanizmy i upravlenie [Transformation of the structure of the economy: mechanisms and management]. Moscow: MAKS Press.

Yaremenko Yu.V. (1997a). Prognozy razvitiya narodnogo khozyaystva i varianty ekonomicheskoy politiki [Forecasts for the development of the national economy and economic policy options]. Moscow: Nauka.

Yaremenko Yu.V. (1997b). Teoriya i metodologiya issledovaniya mnogourovnevoy ekonomiki [Theory and methodology of research multi-level economy]. Moscow: Nauka.

Beath J. (2002). UK Industrial Policy: Old Tunes on New Instruments? Oxford Review of Economic Policy, vol. 18, no. 2, pp. $221-239$.

Cutter B., Litan R., Stangler D. (2016). The Good Economy. Kansas City: Roosevelt Institute and Kauffman Foundation.

Federico G., Foreman-Peck J. (1999). European Industrial Policy: Introduction. In: Foreman-Peck J., Federico G. (eds.). European industrial policy: The twentieth-century experience. N.Y.: Oxford University Press. Pp. 1-17.

Lin J. (2011). New Structural Economics: A Framework for Rethinking Development. World Bank Research Observer, vol. 26, no. 2, pp. 193-221.

Pack H., Saggi K. (2006). Is There a Case for Industrial Policy? A Critical Survey. World Bank Research Observer, vol. 21(2), pp. 267-297.

Phelps E.S. (2007). The Economic Performance of Nations: Prosperity Depends on Dynamism, Dynamism on Institutions. In: Sheshinski E., Strom R.J., Baumol W.J. (eds.). Entrepreneurship, Innovation, and the Growth Mechanism of Free Enterprise Economies. Princeton: Princeton University Press. Pp. 342-356. 
Phelps E.S. (2009). The Good Life and the Good Economy: The Humanist Perspective of Aristotle, the Pragmatists and the Vitalists, and the Economic Justice of John Rawls. In: Kanbur R., Basu K. (eds.). Arguments for a better world: essays in honor of Amartya Sen. Vol. I: Ethics, welfare, and measurement. Oxford - N.Y.: Oxford University Press. Pp. 35-49.

Rodrik D. (2004). Industrial Policy for the Twenty-First Century. Harvard University.

Warwick K. (2013). Beyond Industrial Policy: Emerging Issues and New Trends. OECD Science, Technology and Industry Policy Papers No. 2. OECD Publishing. Available at: http://dx.doi.org/10.1787/5k4869clw0xp-en/.

\title{
Information about the authors
}

\section{Olga A. Romanova}

Dr. Sc. (Econ.), Professor, Chief Researcher. Institute of Economics of the Ural Branch of the RAS (29 Moskovskaya St., Ekaterinburg, 620014, Russia). E-mail: econ@uran.ru.

DOI: $10.29141 / 2218-5003-2019-10-3-2$

\section{Эволюция институтов реализации новой промышленной политики}

\section{О.А. Романова}

\begin{abstract}
Аннотация. Важнейшая особенность экономического развития сегодня заключается в радикальной перестройке мирового индустриального ландшафта, основным инструментом которой является промышленная политика. Однако до настоящего времени не выработано общепринятого понятия промышленной политики, объектов регулирования, нет согласованных целей и механизмов ее проведения. Статья посвящена проблемам эволюционных изменений приоритетов, основным институтам промышленной политики и развитию понятийного аппарата в данной области. Методология исследования базируется на синтезе положений классической институциональной теории, теории долгосрочного технико-экономического развития, новой структурной экономической теории. Использование компаративных методов, а также структурно-логического анализа позволило изучить меняющиеся приоритеты промышленной политики в России, выявить тренды мирового технологического развития, определяющие концептуальные принципы реализации промышленной политики в развитых странах, установить наиболее значимые из них на разных этапах развития отечественной экономики. Результатами исследования выступают: выделение инструментов и форм промышленной политики, способствующих структурной трансформации экономики РФ; обоснование необходимости модификации механизмов и инструментов промышленной политики; определение новых задач, связанных с тенденциями формирования сетевой промышленной политики.
\end{abstract}

Ключевые слова: эволюция; современная промышленная политика; инструменты промышленной политики; формы реализации промышленной политики; бизнес-модель; цифровое государство; платформенная компания; сетевая промышленная политика.

JEL Classification: 014, 025, 032

Финансирование: статья подготовлена в соответствии с планом НИР для Института экономики УрО РАН на 2019 г.

Аата поступления статьи: 26 февраля 2019 г.

Ссыпка Аля цитирования: Романова О.А. Эволюция институтов реализации новой промышленной политики // Управленец. 2019. T. 10. № 3. C. 14-24. DOI: 10.29141/2218-5003-2019-10-3-2.

\section{Источники}

Гительман Л.Д. (2018). Менеджеры, действующие на опережение: университеты и новая индустрия. М.: Экономика.

Грамматчиков А. (2017). Цифровая реальность // Эксперт. № 29(1038). С. 13-17.

Дежина И.Г., Пономарев А.К., Фролов А.С. и др. (2015). Новые производственные технологии: публичный аналитический доклад. М.: Дело.

Дементьев В.Е. (2013). Структурные факторы технологического развития // Экономика и математические методы. Т. 49. № 4. С. 33-46.

Идрисов Г.И., Княгинин В.Н., Кудрин А.Л., Рожкова Е.С. (2018). Новая технологическая революция: вызовы и возможности для России // Вопросы экономики. № 4. С. 5-25.

Ипатова А.В., Шитова А.С. (2018). Институционализация неоиндустриальной промышленной политики: мировой опыт и возможности для России // Экономика и управление. № 10(156). С. 50-59.

Кузнецов Б.В., Симачев Ю.В. (2014). Эволюция государственной промышленной политики в России // Журнал Новой экономической ассоциации. № 2(22). С. 152-179.

Мальцев А.А., Мальцева В.А. (2018). Средний бизнес промышленности региона: динамика роста и структурные сдвиги // Известия Уральского государственного экономического университета. Т. 19. № 6. С. 101-113.

Маркова В.Д. (2018). Бизнес-модели компаний на базе платформ // Вопросы экономики. № 10. С. 127-135.

Ленчук Е.Б. (2016). Новая промышленная политика России в контексте обеспечения технологической независимости. СПб.: Алетия. 
Полтерович В.М. (2018). К общей теории социально-экономического развития. Часть 2. Эволюция механизмов координации // Вопросы экономики. № 12. С. 77-102.

Полтерович В.М., Попов В.В. (2006). Эволюционная теория экономической политики // Вопросы экономики. № 7. С. 4-23.

Попов Е.В., Семячков К.А. (2018). Компаративный анализ стратегических аспектов развития цифровой экономики // Вестник Пермского университета. Сер.: Экономика. Т. 13. № 1. С. 19-36.

Ревенко Л., Ревенко Н. (2017). Международная практика реализации программ развития цифровой экономики // Международные процессы. № 4. С. 20-39.

Сычев Н.В. (2018). Новая стратегия промышленной политики и ее роль в модернизации российской экономики // Экономические стратегии. № 7. С. 32-39.

Тамбовцев В.Л. (2017а). Нуждается ли промышленная политика в теоретических оправданиях? // Вопросы экономики. № 5. C. 29-45.

Тамбовцев В. Л. (2017b). Промышленная политика: к новому пониманию // Известия Уральского государственного экономического университета. № 5(73). С. 54-67.

Татаркин А.И., Романова О.А. (2007). Промышленная политика и механизм ее реализации: системный подход // Экономика региона. № 3. С. 19-31.

Широв А.А. (2018). Трансформация структуры экономики: механизмы и управление. М.: МАКС Пресс.

Яременко Ю.В. (1997а). Прогнозы развития народного хозяйства и варианты экономической политики. М.: Наука.

Яременко Ю.В. (1997b). Теория и методология исследования многоуровневой экономики. М.: Наука.

Beath J. (2002). UK Industrial Policy: Old Tunes on New Instruments? Oxford Review of Economic Policy, vol. 18, no. 2, pp. $221-239$.

Cutter B., Litan R., Stangler D. (2016). The Good Economy. Kansas City: Roosevelt Institute and Kauffman Foundation.

Federico G., Foreman-Peck J. (1999). European Industrial Policy: Introduction. In: Foreman-Peck J., Federico G. (eds.). European industrial policy: The twentieth-century experience. N.Y.: Oxford University Press. Pp. 1-17.

Lin J. (2011). New Structural Economics: A Framework for Rethinking Development. World Bank Research Observer, vol. 26, no. 2, pp. 193-221.

Pack H., Saggi K. (2006). Is There a Case for Industrial Policy? A Critical Survey. World Bank Research Observer, vol. 21 (2), pp. $267-297$.

Phelps E.S. (2007). The Economic Performance of Nations: Prosperity Depends on Dynamism, Dynamism on Institutions. In: Sheshinski E., Strom R.J., Baumol W.J. (eds.). Entrepreneurship, Innovation, and the Growth Mechanism of Free Enterprise Economies. Princeton: Princeton University Press. Pp. 342-356.

Phelps E.S. (2009). The Good Life and the Good Economy: The Humanist Perspective of Aristotle, the Pragmatists and the Vitalists, and the Economic Justice of John Rawls. In: Kanbur R., Basu K. (eds.). Arguments for a better world: essays in honor of Amartya Sen. Vol. I: Ethics, welfare, and measurement. Oxford - N.Y.: Oxford University Press. Pp. 35-49.

Rodrik D. (2004). Industrial Policy for the Twenty-First Century. Harvard University.

Warwick K. (2013). Beyond Industrial Policy: Emerging Issues and New Trends. OECD Science, Technology and Industry Policy Papers No. 2. OECD Publishing. URL: http://dx.doi.org/10.1787/5k4869clw0xp-en/.

\section{Информация об авторе}

\section{РОМАНОВА Ольга Александровна}

Аоктор экономических наук, профессор, главный научный сотрудник. Институт экономики Уро РАН (620014, РФ, г. Екатеринбург, ул. Московская, 29). E-mail: econ@uran.ru. 